\title{
EFFECT OF DIETARY SUPPLEMENTATION OF GARLIC ON FEED CONVERSION RATIO, CARCASS PHYSIOGNOMIES AND HAEMATOLOGICAL PARAMETERS IN BROILERS
}

\author{
M. F. Islam 1 , M. N. Haque ${ }^{2}$, A. Parvin' ${ }^{3}$ M. N. Islam², M. N. Alam¹ and M. H. Sikder ${ }^{*}$ \\ ${ }^{1}$ Department of Pharmacology, Faculty of Veterinary Science, Bangladesh Agricultural University, Mymensingh- \\ 2202; '² Department of Livestock Services, Krishi Khamar Sarak, Farm gate, Dhaka-1215, Bangladesh; \\ ${ }^{3}$ Agribusiness (Animal Health)- ACI Ltd. Dhaka, Bangladesh.
}

\begin{abstract}
One of the widespread spices is garlic which consumed by people of different parts of the world but its valuable growth promoting effect is not sufficiently studied in poultry. Growth promoting effect of garlic in broiler chickens was studied together with its carcass characteristics and blood parameters. Broilers were grouped into four: A (1\%), B (2\%), C (positive control) and D (negative control). Aqueous extract of garlic (1\% and $2 \%)$ was prepared by extraction and were administered with drinking water. A group (1\%) shows best performance with regards to body weight gain rather than B $(2 \%)$, positive and negative control. At the end of experiment ( $35^{\text {th }}$ day), in A group, the live body weight, dressed weight, feed conversion ratio, liver, gizzard, heart, spleen, and pancreas were 1833.2 $\pm 2.1 \mathrm{~g}(\mathrm{P}<0.05), 1229.7 \pm 1.9 \mathrm{~g}(\mathrm{P}<0.05), 1.63(\mathrm{P}<0.05), 47.13 \pm 0.4 \mathrm{~g}$, $26.15 \pm 0.7 \mathrm{~g}, 9.71 \pm 1.8 \mathrm{~g}, 2.21 \pm 0.2 \mathrm{~g}, 2.27 \pm 0.1 \mathrm{~g}$ respectively. The mean Total Erythrocyte Count (TEC), Haemoglobin concentration $(\mathrm{Hb})$ and Packed Cell volume $(\mathrm{PCV})$ were $2.9 \pm 0.1 \mathrm{million} / \mathrm{cm}^{3}, 7.5 \mathrm{~g} \pm 0.2 \mathrm{~g}$, and $25.8 \pm 0.6 \%$, respectively. It is recommended that $1 \%$ aqueous extraction of garlic shows better growth and improved carcass qualities in Broilers.
\end{abstract}

Keywords: Garlic, FCR, growth promoter, broiler.

\section{INTRODUCTION}

In poultry production feed additives are used in poultry feed to improve nutritive value and enhances their performance. Feed is the major component of total costs of poultry venture as $80 \%$ of the total expenditure is on procurement of feed. Antibiotic is intensively used in broiler's ration to improve productivity but it has got negative effects on animaland human health (Noman et al., 2015). However, nowadays use of antibiotics is not only limited but their use in livestock and poultry industry also have been banned in many countries due to the reasons like alteration of natural gut microbiota and drug resistance in bacteria and humans. As a result, to replace them without adversely affecting the performance of birds, natural growth promoters such as prebiotics, probiotics, synbiotics, enzymes, plant extracts, etc., can be used to feed the broilers. Therefore, the use of antibiotic as growth promoters has not been encouraged (Castanon, 2007). Phytogenic feed additives have shown promising effects with regard to weight gain, feed efficiency, lowered mortality and increased livability in poultry(Ahmad and Khan, 2008). Garlic as natural growth promoters can be possible alternatives for common artificial growth promoters like antibiotics. Garlic (Allium sativum) has been used as a spice and a natural medicine for many years. It has influenced antibacterial, antiviral, antiparasitic, antifungal, anticholesteremic, antioxidant, anti-cancerous, and vasodilator characteristics (Hanieh et al., 2010). The garlic has a great influence on haematological parameters, which leads physiological, pathological and nutritional status of poultry (Oleforuh-Okoleh et al., 2015). This is an important spice in traditional cooking of curry in Indian sub-continent and is cheap and available (Huda et al., 2008).Therefore, this study was undertaken to evaluate garlic as a safe growth promoting agent in broiler chicken (Cobb 500).

\section{MATERIALS AND METHODS}

\section{Test elements}

The fresh garlic was bought from local market. The garlic was peeled, cut into small pieces and dried. The dried garlic was crumpled by grinder and aqueous extract was prepared by extraction as described by (Dieumou et al., 2012). After receiving the extraction $1 \%$ and $2 \%$ solution of garlic was freshly prepared for daily need.

*Corresponding e-mail address: drmsikder@bau.edu.bd 


\section{F. Islam and others}

\section{Management of experimental bird's}

A total of 60 day-old Cobb 500 broiler chicks were purchased from Nourish Poultry \& Hatchery Limited, Gazipur, Bangladesh. The chicks were kept for seven days for adaptation and were fed commercial broiler starter feed (Narish poultry Feed, Narish poultry feed limited, Gazipur, Bangladesh) only and given normal drinking water. The brooding temperature was maintained at $35^{\circ} \mathrm{C}$ during 1 st week. It was then gradually lowered by $3{ }^{\circ} \mathrm{C}$ every week until it reached to room temperature (i.e. $25 \pm 1^{\circ} \mathrm{C}$ ). Mean initial weight of the chicks was $36.45 \mathrm{gm}$. at the start of experiment. Newcastle disease vaccination (Baby Chick Ranikhet Disease Vaccine-BCRDV, Livestock Research Institute, Mohakhali, Dhaka, Bangladesh): intraocular at $4^{\text {th }}$ day and $21^{\text {th }}$ day. On day $7^{\text {th }}$ the 60 chicks weighing average body weight of 93 gwere randomly selected to four treatments and a positive and negative control group in a completely randomly design (CRD). The birds were reared in litter system. Four experimental groups were identified as A ( $1 \%$ garlic), B( $2 \%$ garlic), C (negative control: only feed and water) and D (positive control: antibiotic Renamycin ${ }^{\circledR} 20 \mathrm{w} / \mathrm{w}$ Oxytetracycline Hydrochloride USP- Renata Animal Health, Dhaka, Bangladesh supplied as pharmaceuticals recommended dose).

\section{Collection of data}

Daily body weights of all birds were recorded. At the end of treatment blood sample was collected from the wing vein of each bird using disposable plastic syringe and needle with an EDTA. After sacrificed dressing percentage were taken and offal's weight such as the liver, heart, pancreas, gizzard and spleen were recorded.

\section{Haematological assay}

The Packed Cell Volume (PCV), Total Erythrocyte Count (TEC) and Haemoglobin concentrations were done as described by Lamberg and Rothstein (1977).

\section{Statistics and data analysis}

The data were analyzed using general linear model procedure of Statistical Package For Social Science (SPSS) IBM 20and comparison of means tested using Duncan's multiple range test and significance was considered at $\mathrm{p}<0.05$ (Dieumou et al., 2012).

\section{RESULTS AND DISCUSSION}

The effects of feeding different concentration of dietary garlic on daily body weight gain are shown in table 1 . All groups had initial body weight $93.35 \pm 1.4 \mathrm{~g}$. No mortality was detected in all treatment groups throughout the study period. Feed Conversion Ratio (FCR) is shown in the table 2, where significant variation was evident in A. Dressed weights of birds are shown in Table 3; better dressed weight was in A group $(1223.7 \pm 2.1 \mathrm{~g})$. No significance variation was found in offal's weight (Table 4). Significant increases of PCV, Hb and TEC are shown in table 5.

\section{Growth performance}

Daily body weight gain was collected in record log book. In table 1, average weight gain from day 7 to day 35 were described with 7 days interval. Best weight gained by A group at day 35 followed by B, C and lowest in D.

Table 1. Live body weight of birds

\begin{tabular}{lccccc}
\hline \multirow{2}{*}{ Groups } & \multicolumn{5}{c}{ Body weight gain $(\mathrm{gm})$} \\
\cline { 2 - 5 } & Day 7 & Day 14 & Day 21 & Day 28 & Day 35 \\
\hline A & $88.8 \pm 0.4^{\mathrm{b}^{\mathrm{y}}}$ & $311.4 \pm 1.1^{\mathrm{d}}$ & $741.5 \pm 1.7^{\mathrm{a}}$ & $1332.6 \pm 1.8^{\mathrm{b}}$ & $1833.2 \pm 2.1^{\mathrm{a}}$ \\
$\mathrm{B}$ & $90.6 \pm 0.5^{\mathrm{b}}$ & $337.5 \pm 1.1^{\mathrm{a}}$ & $731.1 \pm 1.7^{\mathrm{b}}$ & $1123.8 \pm 1.9^{\mathrm{d}}$ & $1761.5 \pm 1.9^{\mathrm{b}}$ \\
C & $93.2 \pm 0.3^{\mathrm{a}}$ & $3134.5 \pm 1.2^{\mathrm{c}}$ & $711.8 \pm 1.8^{\mathrm{c}}$ & $1357.4 \pm 1.7^{\mathrm{a}}$ & $1761.3 \pm 2.1^{\mathrm{b}}$ \\
D & $91.9 \pm 0.6^{\mathrm{a}}$ & $318.5 \pm 1.1^{\mathrm{b}}$ & $629.5 \pm 2.1^{\mathrm{d}}$ & $1139.3 \pm 2.9^{\mathrm{c}}$ & $1537.5 \pm 2.4^{\mathrm{c}}$ \\
\hline *Different letters
\end{tabular}

*Different letters denote significant variation among the groups 


\section{Effect of dietary supplementation of garlic}

Supplementation of garlic extraction in broiler diet have significant $(\mathrm{P}<0.05)$ influence on body weight gain from 7 days to 35 days of age. The highest mean body weight is gained by $1 \%$ garlic treatment group.

A number of researches reported the growth promoting effect of garlic extract in broiler (Elagib et al., 2013; Noman et al., 2015; Mahmood et al., 2009; Javed et al., 2009; Meraj, 1998). However, how garlic extracts shows growth promoting effect is not decisive. It is suggested, antibacterial compound present in garlic extract (Meraj, 1998), bioactive compound "dialkylpolysulphide". Previous researches on garlic on poultry statistics the gaining of better live weight performances( Elagib et al., 2013).

Mahmood et al. (2009) stated that garlic had positive effect on the growth rate of broiler chicks. Meraj (1998) reported that the existence of antibiotic ingredients in garlic is accountable for the enhancement of weight gain. In consonance, Rehman et al. (2012) reported that mean feed conversion ratio was significantly influenced by water based infusion of garlic. The study findings also support the findings of Javed et al. (2009) which showed a positive effect of aqueous extract of garlic on the performance of broiler chicks in term of FCR and weight gain.

\section{Feed Conversion Ratio (FCR) of birds}

In every 7 days interval FCR was calculated where best FCR was found in A group at $35^{\text {th }}$ day, followed by C, $\mathrm{B}$ and lees feed conversion was observed in $\mathrm{D}$ group.

Table 2. Feed Conversion Ratio (FCR) of birds

\begin{tabular}{llllll}
\hline \multirow{2}{*}{ Groups } & \multicolumn{5}{c}{ Feed Conversion Ratio (FCR) } \\
\cline { 2 - 6 } & Day 7 & Day 14 & Day 21 & Day 28 & Day 35 \\
\hline A & 1.13 & 1.81 & 1.6 & 1.57 & 1.63 \\
B & 1.12 & 1.75 & 1.7 & 1.63 & 1.77 \\
C & 1.12 & 1.74 & 1.8 & 1.66 & 1.73 \\
D & 1.11 & 1.82 & 1.97 & 1.92 & 1.94 \\
\hline
\end{tabular}

Significant $(\mathrm{P}<0.05)$ difference were revealed for FCR in all the treatments from 7 days to 35 days of age. Poor FCR was observed in negative control group and better FCR was observed in $1 \%$ garlic group. According to Senthil Kumar et al.,(2015) the FCR of broiler shows garlic extraction has better affect on FCR.

\section{Dressed weight}

At day 35, after dressing of each bird they were individually weighted. Among the groups A obtained highest dressed weight followed by C, B and lowest dressed weight was in D group.

Table 3. Dressed weight of birds

\begin{tabular}{lc}
\hline Group & Weight of dressed birds (gm) \\
\hline A & $1233.56 \pm 1.9^{\mathrm{a}}$ \\
B & $1061.23 \pm 1.8^{\mathrm{c}}$ \\
C & $1103.0 \pm 2.1^{\mathrm{b}}$ \\
D & $994.3 \pm 2.2^{\mathrm{d}}$ \\
\hline
\end{tabular}

*Different letters denotes significant variation among the groups

The dressed weight of birds was gained more in $1 \%$ garlic treatment group than others $(\mathrm{P}<0.05)$.

\section{Offal's weight of birds}

Individual bird's liver, gizzard, hear, spleen and pancreas weight was taken and no statistical significance was observed $(\mathrm{P}<0.05)$. 


\section{F. Islam and others}

Table 4. Offal's weight of birds after dressing at day 35

\begin{tabular}{lccccc}
\hline \multirow{2}{*}{ Groups } & \multicolumn{5}{c}{ Offal's weight of birds $(\mathrm{gm})$} \\
\cline { 2 - 6 } & Liver & Gizzard & Heart & Spleen & Pancreas \\
\hline A & $47.13 \pm 0.4^{\mathrm{b}}$ & $26.15 \pm 0.7^{\mathrm{a}}$ & $9.71 \pm 1.8^{\mathrm{a}}$ & $2.21 \pm 0.2^{\mathrm{a}}$ & $2.27 \pm 0.1^{\mathrm{a}}$ \\
B & $53.25 \pm 0.5^{\mathrm{a}}$ & $22.19 \pm 0.3^{\mathrm{b}}$ & $10.01 \pm 1.9^{\mathrm{b}}$ & $2.87 \pm 0.1^{\mathrm{a}}$ & $2.35 \pm 0.1^{\mathrm{a}}$ \\
C & $53.15 \pm 0.4^{\mathrm{b}}$ & $22.61 \pm 0.4^{\mathrm{b}}$ & $11.01 \pm 1.7^{\mathrm{b}}$ & $2.57 \pm 0.1^{\mathrm{a}}$ & $2.74 \pm 0.2^{\mathrm{a}}$ \\
D & $52.61 \pm 0.4^{\mathrm{a}}$ & $18.81 \pm 0.5^{\mathrm{c}}$ & $10.136 \pm 1.8^{\mathrm{b}}$ & $2.49 \pm 0.1^{\mathrm{a}}$ & $2.46 \pm 0.1^{\mathrm{a}}$ \\
\hline
\end{tabular}

*Different letters denotes significant variation among the groups

The results shown no significant differences $(\mathrm{P}<0.05)$ between all treatment groups in offal's $($ liver, gizzard, heart, spleen and pancreas) weight of bird. The decrease in weight of liver of birds on supplemented diets contrast with the earlier report of Tchakounte et al. (2006) where liver and the gizzard of birds on supplemented diets were more developed thus indicating an intense activity of these organs. The higher body weight and lower offal's weight indicates the best performance (Plumber and Kiepper, 2011).

\section{Haematological assay}

After collection of blood with anticoagulant (EDTA), TEC, Hb and PCV were performed at department of physiology, Bangladesh Agricultural University, Mymensingh. No significance variation was found but significance increase was found among the groups.

Table 5. Hematological data

\begin{tabular}{ccccccc}
\hline \multirow{2}{*}{ Group } & \multicolumn{3}{c}{ Mean } & \multicolumn{3}{c}{ Standard Deviation } \\
\cline { 2 - 7 } & TEC $\left(\right.$ million $\left./ \mathrm{cm}^{3}\right)$ & $\mathrm{Hb}(\mathrm{g})$ & $\mathrm{PCV}(\%)$ & $\mathrm{TEC}\left(\mathrm{million} / \mathrm{cm}^{3}\right)$ & $\mathrm{Hb}(\mathrm{g})$ & $\mathrm{PCV}(\%)$ \\
\hline $\mathrm{A}$ & 2.9 & 7.5 & 25.8 & 0.1 & 0.2 & 0.6 \\
$\mathrm{~B}$ & 2.9 & 7.4 & 29.7 & 0.1 & 0.2 & 1.0 \\
$\mathrm{C}$ & 2.2 & 7.4 & 23.3 & 0.2 & 0.3 & 3.7 \\
$\mathrm{D}$ & 2.3 & 6.9 & 21.1 & 0.2 & 0.3 & 3.6 \\
\hline
\end{tabular}

There was significant increase $(\mathrm{P}<0.05)$ in the $\mathrm{PCV}, \mathrm{Hb}$ and TEC of birds on the garlic extraction than other treatments. The increasing of $\mathrm{PCV}, \mathrm{Hb}$, and $\mathrm{RBC}$ contents of the blood is an indication of improved oxygen carrying capacity of the cells which translated to a better availability of nutrients to the birds consequently affecting their well-being (Oleforuh-Okoleh et al., 2015).Administration of garlic statistically reduced the platelets in the blood. Lawson et al. (1992) reported that preventing the transformation of arachidonic acid to thromboxane and decreasing the sensitivity of platelets to aggregating agents may be possible with the administration of garlic in fatty diets. This implies that garlic could be potentially useful in improving blood circulation on account of its inhibitory effects on platelet aggregation

\section{CONCLUSION}

Aqueous extract of garlic displays better performance than positive and negative control groups. Among garlic extractions, $1 \%$ garlic extracts exhibits best performance in relation to carcass weight and others. As it is organic in nature, positive effects on consumer's health are observable. Consequently, it is recommended that garlic extract can be used as the substitute organic growth promoter in poultry.

\section{REFERENCES}

1. Ahmad T and Khan S (2008). Evaluation of different medicinal plants as growth promoters for broiler chicks. Sarhad Journal of Agriculture 24: 323-330.

2. Al-Kassie GAM (2009). Influence of two plant extracts derived from thyme and cinnamon on broiler performance. Pakistan Veterinary Journal 29: 169-173.

3. Castanon JIR (2007). History of the use of antibiotic as growth promoters. Journal of Poultry Science 86: 2466-2471. 
4. Dieumou FE, Teguia A, Kuiate JR, Tamokou JD and Doma UD (2012). Effect of diets fortified with garlic organic extract and streptomycin sulphate on growth performance and carcass characteristics of broilers. International Journal of Livestock Production 3: 36-42.

5. Elagib HAA, El-Amin WIA, Elamin KM and Malik HEE (2013). Effect of dietary garlic (Allium sativum) supplementation as feed additive on broiler performance and blood profile. Journal of Animal Science Advances 3: 58-64.

6. Huda FA, Islam MS, HB and MS (2008). Impact assessment study on selected spice crops under action plan in Bangladesh. Progressive Agriculture 19: 229-241.

7. Hanieh H, Narabara K, Piao M, Gerile C, Abe A and Kondo Y (2010). Modulatory effects of two levels of dietary Alliums on immune responses. Animal Science Journal 81: 673-680.

8. Javed M, Durrani F, Hafeez A, Khan RU and Ahmad I (2009). Effect of aqueous extract of plant mixture on carcass quality of broiler chicks. ARPN Journal of Agricultural and Biological Science 4: 37-40.

9. Lamberg SL and Rothstein R, 1977. Laboratory Manual of Hematology and Urinalysis, West Port Connecticut, USA: Avi. Publishing Company, Inc.

10. Lawson LD, Ransom DK and Hughes B G (1992). Inhibition of whole blood platelet-aggregation by compounds in garlic clove extracts and commercial garlic products. Thrombosis Research 65: 141-156.

11. Mahmood S, Hassan MM, Alam M and Ahmad F (2009) Comparative efficacy of Nigella sativa and Allium sativum as growth promoters in broilers. International Journal of Agriculture and Biology 11: 775-778.

12. Meraj ICA (1998). Effect of garlic and neem leaves supplementation on the performance of broiler chickens. M. Sc. Thesis, Department of Poultry Science, University of Agriculture, Faisalabad, Pakistan.

13. Noman ZA, Hasan MM, Talukder S, Sarker YA, Paul TK and Sikder MH (2015). Effects of garlic extract on growth, carcass characteristics and haematological parameters in broilers. The Bangladesh Veterinarian 32: $1-6$.

14. Rehman ZU, Khan S, Chand N, Tanweer AJ, Sultan A, Akhtar A and Tauqeer AM (2012). Effect of water based mixture infusion of Allium sativum and Withania somnifera on performance of broiler chicks. Pakistan Journal of Science 64: 180-183.

15. Oleforuh-Okoleh VU, Ndofor-Foleng HM, Olorunleke SO and Uguru JO (2015). Evaluation of growth performance, haematological and serum biochemical response of broiler chickens to aqueous extract of ginger and garlic. Journal of Agricultural Science 7: 167-174.

16. Plumber HS and Kiepper BH (2011). Impact of poultry processing by-products on wastewater generation, treatment and discharges. In Proceedings of the 2011 Georgia Water Resources Conference.

17. Senthilkumar S, Madesh N, Purushothaman MR, Vasanthakumar P, Thirumalaisamy G and Sasikumar P (2015). Effect of garlic supplementation on performance in broilers - a review. International Journal of Science, Environment and Technology 4: 980-983.

18. Tchakounte J, Bopelet M, Ngoungoupayou JD, Dongmo T, Meffeja F and Fotso J (2006). Influence de la consommation de la boue d'huile de palme sur les performances zootechniques et économiques des poulets de chair en phase definition. Livestock Research for Rural Development 18: 173. 